\title{
Investigation on Durability and Reactivity of Promising Metal Oxide Sorbents During Sulfidation and Regeneration
}

\author{
Quarterly Report \\ October 1 - December 31, 1996
}

Work Performed Under Contract No.: DE-FG21-94MC31206

RECEIVED

APR 151997

For

OSTI

\author{
U.S. Department of Energy \\ Office of Fossil Energy \\ Mórgantown Energy Technology Center \\ P.O. Box 880 . \\ Morgantown, West Virginia 26507-0880
}

Htt

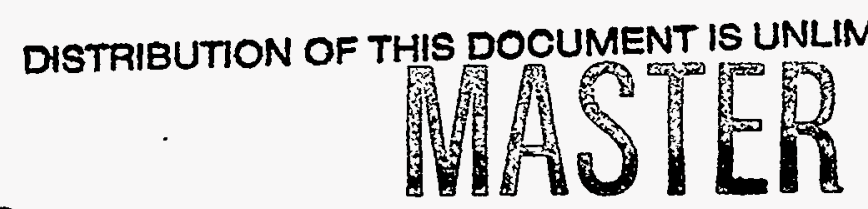

Chemical Engineering Department

College of Engineering, Architecture and Physical Sciences

Tuskegee University

Tuskegee, Alabama 36088 


\section{Disclaimer}

This report was prepared as an account of work sponsored by an agency of the United States Government. Neither the United States Government nor any agency thereof, nor any of their employees, makes any warranty, express or implied, or assumes any legal liability or responsibility for the accuracy, completeness, or usefulness of any information, apparatus, product, or process disclosed, or represents that its use would not infringe privately owned rights. Reference herein to any specific commercial ptoduct, process, or service by trade name, trademark, manufacturer, or otherwise does not necessarily constitute or imply its endorsement, recommendation, or favoring by the United States Government or any agency thereof. The views and opinions of authors expressed herein do not necessarily state or reflect those of the United States Government or any agency thereof. 


\section{DISCLAIMER}

Portions of this document may be illegible in electronic image products. Images are produced from the best available original document. 


\section{CONTENTS}

\section{Page}

DISCLAIMER

iii

LIST OF TABLES

v

LIST OF FIGURES

V

MILESTONES

1

EXECUTIVE SUMMARY

1

INTRODUCTION

1

EXPERIMENTAL SETUP

2

STATUS OF THIS RESEARCH PROJECT

4

PRESENTATION

PLANS ON FUTURE EXPERIMENTS 


\section{LIST OF TABLES}

Table Page

1 The following major equipment have been placed on order 5

2 The following parts and supplies have been placed on order.

6

\section{LIST OF FIGURES}

Figure

Page

1 A differential reactor.

2

2 A differential reactor assembly

3 


\section{SCHEDULE AND MILESTONES}

\begin{tabular}{|c|c|c|c|c|c|c|c|c|c|c|c|c|c|c|c|c|c|c|c|c|c|c|c|c|}
\hline & \multicolumn{12}{|c|}{ FY 1994-1995 } & \multicolumn{12}{|c|}{ FY 1995-1996 } \\
\hline & $\overline{0}$ & $\mathrm{~N}$ & $\mathrm{D}$ & $\mathbf{J}$ & $\mathrm{F}$ & $M$ & $\mathrm{~A}$ & $\bar{M}$ & & $\mathbf{J}$ & A & $\mathrm{s}$ & 0 & $\mathrm{~N}$ & D & $\mathrm{J}$ & $F$ & & A & M & $\mathbf{J}$ & $\mathrm{J}$ & A & $\mathrm{s}$ \\
\hline Procurements of Materials and Equipment & & & & & & & & & & & & & & & & & & & & & & & & \\
\hline Fabriction of a Micro Batch Resctor & & & & & & & & & & & & & & & & & & & & & & & & \\
\hline $\begin{array}{l}\text { Development of Analytycan Procedures for } \\
\text { Concentrations of Sulfur compounds }\end{array}$ & & & & & & & & & & & & & & & & & & & & & & & & \\
\hline $\begin{array}{l}\text { Development of Experimential Procedures for } \\
\text { Sulfidution Reaction of Fresh Metal Oxide } \\
\text { Sortents }\end{array}$ & & & & & & & & & & & & & & & & & & & & & & & & \\
\hline $\begin{array}{l}\text { Formulation of Durble Metal Oxide Sorbents } \\
\text { with Hight-Sulfur Removal Capacity }\end{array}$ & & & & & & & & & & & & & & & - & & & & & & & & & \\
\hline $\begin{array}{l}\text { Reaction Kinetics on Sulfidation of Metul Oxide } \\
\text { Sorbents }\end{array}$ & & & & & & & & & & & & & & & & & & & & & & & & \\
\hline $\begin{array}{l}\text { Recetion Kinctics on Regeneration of Sulfur- } \\
\text { loaded Metal Oxide Sorbents }\end{array}$ & & & & & & & & & & & & & & & & & & & & & & & & \\
\hline $\begin{array}{l}\text { Development of an Intraparticle Diffusivity } \\
\text { Model for Sulfidation of Metal Oxide Sorbents }\end{array}$ & & & & & & & & & & & & & & & & & & & & & & & & \\
\hline $\begin{array}{l}\text { Delincestion of Erecects of Hydrogen Pantial } \\
\text { Pressures and Moistre Amounts on Sulfidation } \\
\text { of Metal Oxide Sortents }\end{array}$ & & & & & & & & & & & & & & & & & & & & & & & & \\
\hline $\begin{array}{l}\text { Equilibrium Absopption of Hydrogen Sulfide into } \\
\text { Metal Oxide Sorbents }\end{array}$ & & & & & & & & & & & & & & & & & & & & & & & & \\
\hline Development of a Micro Differential Reactor & & & & & & & & & & & & & & & & & & & & & & & & \\
\hline
\end{tabular}

\section{EXECUTIVE SUMMARY}

The main objectives of this research project during this quarter are to design a micro differential reactor, design a differential reactor assembly, and select and order necessary parts as well as accessories for the reactor and its assembly.

\section{INTRODUCTION}

Reactivity of formulated metal oxide sorbents was tested in the past, using a micro batch reactor. The temperature of the reactor is maintained at a desired constant temperature by submerging the reactor into a heated fluidized sand bath. For a short reaction duration, it is difficult to control a reaction temperature at a desired one. Since the temperature of the micro batch reactor is increased from room temperature to a desired reaction temperature for a short reaction duration, experimental reproducibility is poor.

Reaction of formulated metal oxide sorbents with hot wet hydrogen sulfide is rapid, and most of 100- 200 mesh formulated metal oxide sorbent particles are reacted with hot wet hydrogen sulfide for a short reaction duration. Reactivity of formulated metal oxide sorbents in the micro batch reactor was tested for the reaction duration range of $30-120$ seconds to find initial reaction rates of formulated sorbents with wet hydrogen 
sulfide. Reactivity of formulated metal oxide sorbents in the micro batch reactor can not be tested below 30 second reaction duration due to the difficulty in controlling a reaction temperature at a desired one. A newly-fabricated differential reactor will generate reaction data, which can not be obtained with a batch reactor.

\section{EXPERIMENTAL SETUP}

A differential reactor mainly consists of a 1" Swagelok cap and a 1" Swagelok plug. A 1" Hastelloy C frit welded to the 1" Swagelok plug, which-becomes as a . bottom part of the reactor, whereas a 3/4" Hastelloy $C$ frit welded to the 1" Swagelok cap, which becomes as a top part of the reactor (see Figure 1).

Figure 1. A Differential Reactor

Bottom Part of the Reactor

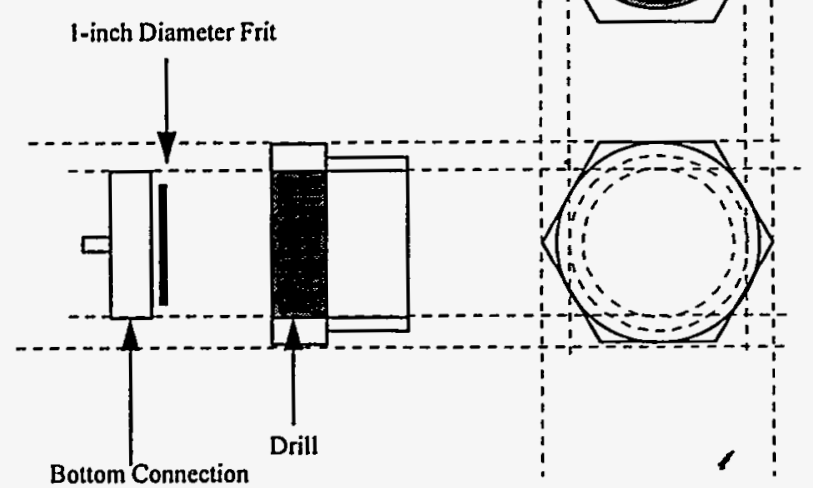

Top Part of the Reactor

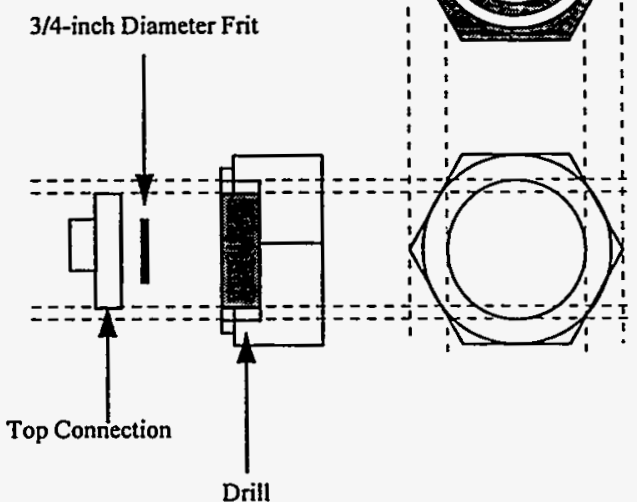

A differential reactor assembly mainly consists of four mass flow meters for gases, one differential reactor, one preheater, one high pressure liquid pump for water, one four-way switch valve, one muffle furnace, three filters for gases, four check valves, and one water collection bottle (see Figure 2). 
Figure 2. A Differential Reactor Assembly

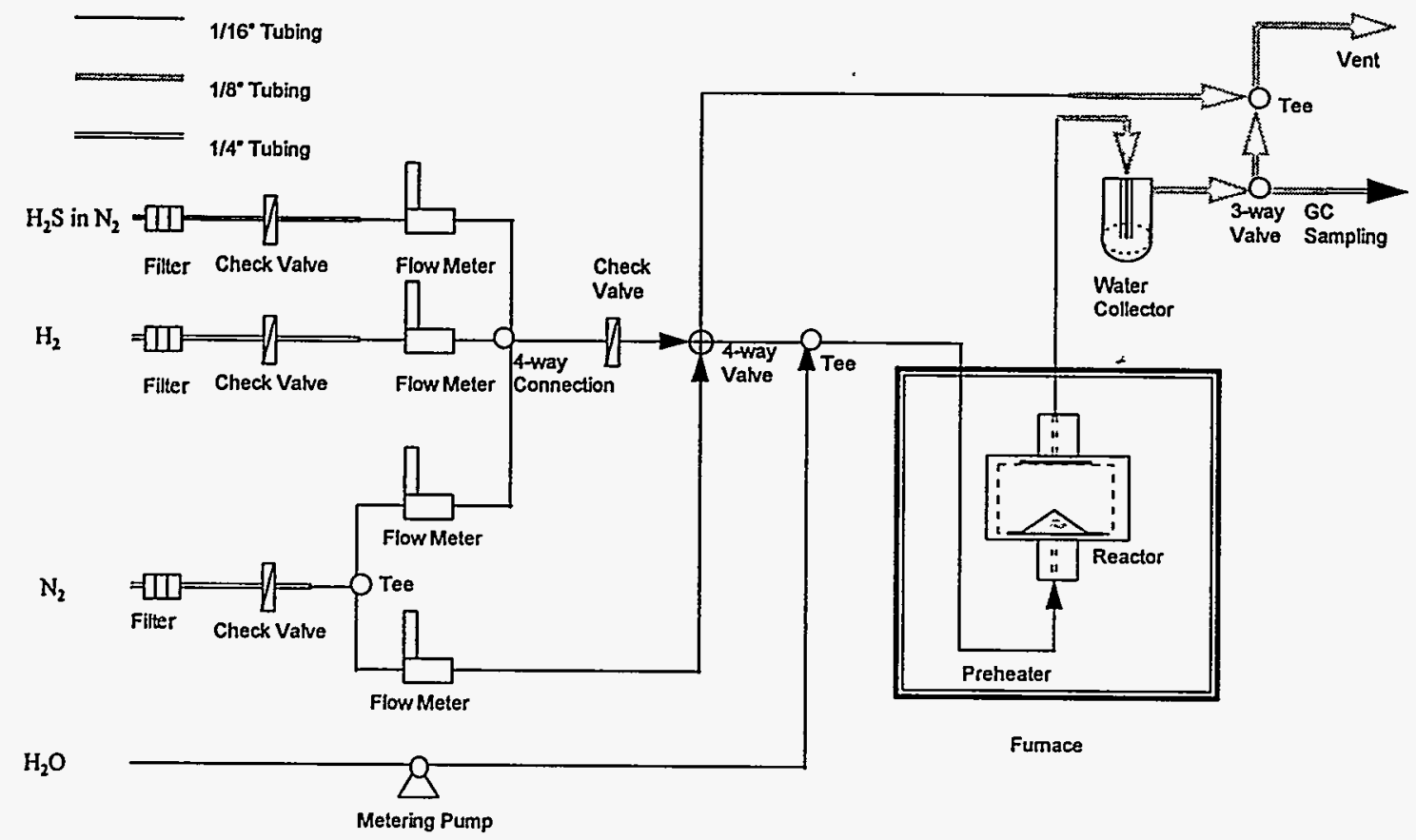

A length of a preheater for a feed stream to the reactor is calculated from the following equations.

$$
\begin{aligned}
& \frac{h d}{k}=3.66+\frac{0.0668 \frac{d}{L} \operatorname{Re} \operatorname{Pr}}{1+0.04\left[\left(\frac{d}{L}\right) \operatorname{Re} d \operatorname{Pr}\right]^{\frac{2}{3}}} \\
& \operatorname{Re}=\frac{4 m}{\pi d \mu} \\
& \operatorname{Pr}=\underline{C p}
\end{aligned}
$$

where $h$ : heat transfer coefficient

$k$ : thermal conductivity of a gas mixture

$d$ : diameter of a preheater

$L$ : length of a preheater

Re: Reynolds number of the flow of a gas mixture in a preheater.

Pr: Prandtl number

$\mathrm{m}$ : mass flow rate of a gas mixture

$\mu$ : viscosity of a gas mixture

$\mathrm{Cp}$ : heat capacity of a gas mixture 
Initial reactivity of formulated metal oxide sorbents with hot wet hydrogen sulfide in the batch reactor was tested by analyzing concentrations of hydrogen sulfide with a gas chromatograph, whereas initial reactivity of formulated metal oxide sorbents with hot wet hydrogen sulfide in a differential reactor was tested by measuring weights of sulfided metal oxide sorbents

A diffferential reactor was designed to test accurately initial reactivity of formulated metal oxide sorbents. Initial reactivity of formulated metal oxide sorbents with hot wet hydrogen sulfide in the differential reactor can be tested for any desired reaction duration. Reactive interaction of the reactor wall itself with hot wet hydrogen sulfide does not affect significantly experimental data generated from the differential reactor in comparison with those generated from the batch reactor.

The reactor containing a sorbernt for a test is preheated at a desired temperature with hot wet nitrogen from a preheater placed in a muffle furnace. A reaction mixture containing hydrogen sulfide, hydrogen, moisture and nitrogen also is preheated at a desired temperature by flowing the mixture in the preheater placed in the isothermal muffle furnace. The reaction starts by switching the wet nitrogen feed stream with the wet reaction mixture feed stream to the reactor. A reaction duration is controlled by switching the reaction mixture feed stream with the nitrogen feed stream at a desired reaction duration.

A moisture content in a reaction mixture is controlled by using a high pressure water pump. Concentrations of hydrogen sulfide, hydrogen and nitrogen in a simulated hot wet coal gas mixture are controlled with its individual mass flow meter. The temperature of the micro batch reactor is maintained up to $550^{\circ} \mathrm{C}$, whereas the temperature of the differential reactor is maintained up to $1000^{\circ} \mathrm{C}$ to test initial reactivity of formulated metal oxide sorbents.

\section{STATUS OF THIS RESEARCH PROJECT}

Research activities and efforts of this research project were concentrated on designing a micro differential reactor as well as a differential reactor assembly, and selecting and ordering necessary parts as well as accessories for the reactor and its assembly (see Tables 1 and 2) for this reseárch project during the period of October-December 1996.

Experiments on initial reactivity of sorbents were not performed due to failures of heating elements as well as the old existing temperature controller for the fluidized sandbath. The replacement parts are not available for the temperature controller. A new temperature controller for the fluidized sandbath has been ordered (see Table 1). 
Table 1. The following major equipment have been placed on order.

\begin{tabular}{|c|c|c|}
\hline Item No. & Equipment/Description & Supplier \\
\hline 1 & $\begin{array}{l}\text { OMNIFIT Glass Solvent Bottle, } 100 \mathrm{ml} \text { plastic coated clear, } \\
3 \text { valves, } 15 \mathrm{psi}, 1 / 8 \text { " OD tubing }\end{array}$ & BODMAN Industies \\
\hline 2 & 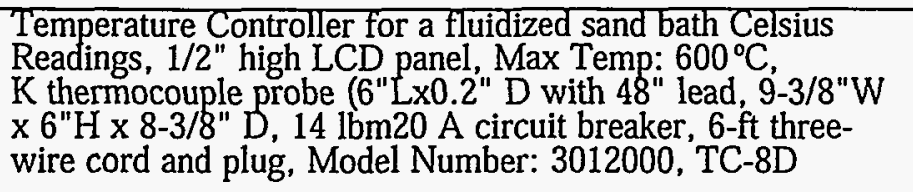 & Techne Incorporated \\
\hline 3 & $\begin{array}{l}\text { FLOW CONTROL SYSTEM, } 500 \mathrm{ml} / \mathrm{min} \text { (scc/min), Wetted } \\
\text { Materials: anoized aluminum, } 316 \text { stainless steel, silicone } \\
\text { elastomer, and NORYL, DC power adapter, Max pressure: } \\
100 \text { psi, Max temperature: } 50^{\circ} \mathrm{C} \text { Built-in miniature } \\
\text { proportional valve and controller }\end{array}$ & $\begin{array}{l}\text { Cole-Parmer Instrument } \\
\text { Company }\end{array}$ \\
\hline 4 & $\begin{array}{l}\text { FLOW CONTROL SYSTEM, } 500 \mathrm{ml} / \mathrm{min} \text { (scc/min), Wetted } \\
\text { Materials: anoized aluminum, } 302 \text { stainless steel, silicone } \\
\text { elastomer, and NORYL, DC power adapter, Max pressure: } \\
100 \text { psi, Max temperature: } 50^{\circ} \mathrm{C} \text {, Built-in miniature } \\
\text { proportional valve and controller }\end{array}$ & $\begin{array}{l}\text { Cole-Parmer Instrument } \\
\text { Company }\end{array}$ \\
\hline 5 & $\begin{array}{l}\text { FLOW CONTROL SYSTEM, } 100 \mathrm{ml} / \mathrm{min} \text { (scc/min), Wetted } \\
\text { Materials: anoized aluminum, } 302 \text { stainless steel, silicone } \\
\text { elastomer, and NORYL, DC power adapter, Max pressure: } \\
100 \text { psi, Max temperature: } 50^{\circ} \mathrm{C} \text { Built-in miniature } \\
\text { proportional valve and controller }\end{array}$ & $\begin{array}{l}\text { Cole-Parmer Instrument } \\
\text { Company }\end{array}$ \\
\hline 6 & $\begin{array}{l}\text { FLOW CONTROL SYSTEM, } 200 \mathrm{ml} / \mathrm{min}(\mathrm{scc} / \mathrm{min}), \text { Wetted } \\
\text { Materials: anoized aluminum, } 302 \text { stainless steel, silicone } \\
\text { elastomer, and NORYL, DC power adapter Max pressure: } \\
100 \text { psi, Max temperature: } 50^{\circ} \mathrm{C} \text { Built-in miniature } \\
\text { proportional valve and controller }\end{array}$ & $\begin{array}{l}\text { Cole-Parmer Instrument } \\
\text { Company }\end{array}$ \\
\hline 7 & $\begin{array}{l}\text { KahI Pellet Hardness Tester, Pellet Diameter: } 2-22 \mathrm{~mm} \text {, } \\
\text { Hardness Range: } 0.25 \mathrm{~kg}-1 \mathrm{~kg} \text {, chromed steel, } 2 \text { pounds }\end{array}$ & LCI Corporation \\
\hline
\end{tabular}


Table 2. The following parts and supplies have been placed on order.

\begin{tabular}{|c|c|c|}
\hline Item No. & Parts \& Supplies/Description & Supplier \\
\hline 1 & 1" hastelloy C Frit, $2 \mu \mathrm{m}$ & Valco Instrument Co. Inc. \\
\hline 2 & $1 / 16 "$ OD $0.03 "$ 'ID hastelloy C Tubing, $8 \mathrm{ft}$ & Valco Instrument Co. Inc. \\
\hline 3 & $\begin{array}{l}\text { Unidirectional Nupro check valve, } 316 \text { SS, cracking } \\
\text { pressure of } 20 \text { psig, } 6000 \mathrm{psig}, 400^{\circ} \mathrm{F} \text {, neoprene seal, } 1 / 4^{\prime \prime} \\
\text { Swagelok connection }\end{array}$ & $\begin{array}{l}\text { Birmingham Valves \& } \\
\text { Fitting Co }\end{array}$ \\
\hline 4 & 1/16" Valco nut, 300 series SS, $0.75^{\prime \prime}$ long, & Alltech Associates, Inc \\
\hline 5 & $\begin{array}{l}\text { 1/16" 4-port Switch Valve, } 316 \mathrm{SS}, 400 \mathrm{psig}, 175^{\circ} \mathrm{C} \text {, } \\
\text { Carbon-filled Teflon seal }\end{array}$ & Alltech Associates, Inc \\
\hline 6 & 1"-diameter $0.063 "$-thick 2 - $\mu \mathrm{m}$-pore 316 -SS Frit & Alltech Associates, Inc \\
\hline 7 & $\begin{array}{l}\text { 1/16" PEEK Tee, } 0.8 \mathrm{~mm} \text { bore, } 1 / 4-28 \text { UNF thread, } \\
100^{\circ} \mathrm{C}, 500 \mathrm{psig}\end{array}$ & Alltech Associates, Inc \\
\hline$\overline{8}$ & $\begin{array}{l}\text { 1/16" PEEK cross, } 0.8 \mathrm{~mm} \text { bore, } 1 / 4-28 \text { UNF thread, } 500 \\
\text { psig, } 100^{\circ} \mathrm{C}\end{array}$ & Alltech Associates, Inc \\
\hline 9 & 1/16" Valco Ferrules, $316 \mathrm{SS}, 10 / \mathrm{pk}$ & Alltech Associates, Inc \\
\hline 10 & $\begin{array}{l}\text { Fingertight nuts for } 1 / 16^{\prime \prime} \text { OD tubing, polypropylene, } \\
\text { natural color, } 1 / 4-28 \mathrm{UNF} \text { thread } 500 \mathrm{psig}, 100^{\circ} \mathrm{C}, 10 / \mathrm{pk}\end{array}$ & Alltech Associates, Inc \\
\hline 11 & $\begin{array}{l}\text { Tetzel } 1 / 16 \text { " bore frange-free ferrules } \\
\text { 10/pk, } 1 / 4-28 \text { UNF thread }\end{array}$ & Alltech Associates, Inc \\
\hline 12 & 1/16" OD 0.05" ID 316 SS Tubing & Alltech Associates, Inc \\
\hline 13 & PTFE Cones for 1/8" OD Tubing, Omnifit, 4/pk & Alltech Associates, Inc \\
\hline 14 & $\begin{array}{l}\text { Female } 1 / 4-28 \text { UNF to Female } 10-32 \text { UNF, PEEK internal } \\
\text { union, } 2 / \mathrm{pk} \text {, }\end{array}$ & Alltech Associates, Inc \\
\hline 15 & $\begin{array}{l}\text { Finger-tight nuts for } 1 / 8^{\prime \prime} \text { OD tubing, } 1 / 4-28 \mathrm{UNF} \text { thread, } \\
\text { natural color, finger-tight nut, polypropolene, } 10 / \mathrm{pk}\end{array}$ & Alltech Associates, Inc \\
\hline 16 & Flange-free ferrules for $1 / 8$ " bore, Tefzel, $10 / \mathrm{pkg}$ & Alltech Associates, Inc \\
\hline 17 & $\begin{array}{l}\text { One-piece fingertight nuts, } 1 / 16 " \text { OD tubing, } 10-32 \text { UNF } \\
\text { thread, } 10 / \mathrm{pk} \text {, natural color }\end{array}$ & Alltech Associates, Inc \\
\hline 18 & $1 / 4^{\prime \prime}$ brass gas-line filter , $7 \mu \mathrm{m}$ filter & Spelco, Inc. \\
\hline 19 & $1 / 4$ " stainless steel T-type line filter, $7 \mu \mathrm{m}$ filter & Spelco, Inc \\
\hline
\end{tabular}




\section{PRESENTATION}

A research paper, entitled "Reactivity of Promising Metal Oxide Sorbents for Removal of Hydrogen Sulfide from Hot Coal Gases", was presented for the Session 110-Reactive Separation Processes I at 3:35 PM, November 13, 1996, the 1996 Annual AIChE Meeting, Chicago, November 10 -15, 1996. Our paper was replaced with the paper 110d, entitled "Development of New Packings for Catalytic Distillation" by Ishida.

A research paper, entitled "Formulation of Metal Oxide Sorbents for Removal of Wet Hydrogen Sulfide", was accepted for presentation at the 1997 Spring National AIChE Meeting, Houston, March 9 - 13, 1997.

A research paper, entitled "Reactivity of Metal Oxide Sorbents for Removal of Wet Hydrogen Sulfide at High Temperatures", was submitted for publication in the proceedings for the Fifth Annual HBCU/Private Sector-Energy Research and Development Technology Transfer Symposium, Baton Rouge, Louisiana, March 4-5, 1997

\section{PLANS ON FUTURE EXPERIMENTS}

Various metal oxide sorbents will be formulated with various additives under various formulation conditions in order to search for a formula of a durable sorbent with high-sulfur-absorbing capacity. Initial reactivity of formulated metal oxide sorbents will be tested with the batch reactor as well as the newly-fabricated differential reactor. Hardness of formulated metal oxide sorbents will be tested with a Kahl pellet hardness tester, which has been placed on order (see Table 1). 